\title{
Influence of Estrus of Dairy Goats on Somatic Cell Count, Milk Traits, and Sex Steroid Receptors in the Mammary Gland
}

\author{
P. Moroni, ${ }^{\star 1}$ G. Pisoni,† G. Savoini,† E. van Lier,ł S. Acuña,\# J. P. Damián,\# and A. Meikle\# \\ *Department of Veterinary Pathology, Hygiene and Public Health, and \\ †Department of Veterinary Sciences and Technologies for Food Safety, University of Milan, via Celoria 10, 20133 Milan, Italy \\ $\ddagger$ Animal and Forage Sciences Department, Faculty of Agriculture, and \\ \#Department of Molecular and Cellular Biology, Veterinary Faculty, University of Uruguay, Montevideo, Uruguay
}

\begin{abstract}
Two experiments were conducted to study the effect of the stage of a spontaneous estrus cycle on milk yield and constituents [somatic cell count (SCC), fat, protein, caseins, lactose, and urea content] and on estrogen receptor- $\alpha(\mathrm{ER} \alpha)$ and progesterone receptor $(\mathrm{PR})$ immunostaining in the mammary gland. In experiment I, the major components of milk and SCC were monitored weekly in 80 lactating Saanen goats for 6 wk, whereas detection of estrus was daily. In experiment II, milk samples were collected daily for SCC determination during 1 spontaneous estrus (d 0 ) until the second spontaneous estrus in 14 Saanen goats. The day of the estrous cycle was confirmed by plasma progesterone and $17 \beta$-estradiol levels. Immunoreactivity of $\mathrm{ER} \alpha$ and PR was analyzed in mammary gland samples of 8 Saanen goats $(\mathrm{d} 0, \mathrm{n}=4 ; \mathrm{d} 10, \mathrm{n}=4)$ and the number of positive nuclei and intensity of the staining were evaluated in 1,000 cells. In experiment I, milk casein and protein percentages were significantly affected by the stage of estrous cycle; during proestrus and estrus, these variables were higher $(3.32 \pm 0.06$ and $4.44 \pm 0.08)$ than during metestrus ( $3.03 \pm 0.07$ and $4.07 \pm 0.10$ ), but not higher than during diestrus ( $3.23 \pm 0.06$ and $4.35 \pm 0.09$, respectively). In experiment II, daily measurement of SCC revealed higher levels at estrus $\left(7,195 \pm 672 \times 10^{3}\right.$ cells $/ \mathrm{mL})$ and a decline toward the luteal phase $(1,694$ $\pm 672 \pm 10^{3}$ cells $/ \mathrm{mL}$ ). Estrogen receptor- $\alpha$ and PR immunostaining were exclusively detected on epithelial cells. The percentage of positive nuclei to $\mathrm{ER} \alpha$ was higher on $\mathrm{d} 0$ than on $\mathrm{d} 10(75.4 \pm 8.8$ vs. $68.3 \pm 8.8 \%)$, but no change was observed for PR $(4.0 \pm 0.3$ vs. $3.5 \pm$ $0.4 \%)$. The average immunostaining intensity for both receptors was greater on d 0 than on d 10 (ER $\alpha: 1.44$ \pm 0.02 vs. $1.35 \pm 0.02$; PR: $0.079 \pm 0.008$ vs. $0.057 \pm$ 0.008). The high SCC at estrus in experiment II was
\end{abstract}

Received July 17, 2006.

Accepted August 29, 2006

${ }^{1}$ Corresponding author: paolo.moroni@unimi.it associated with high plasma estradiol and low progesterone, suggesting that the increased SCC could be brought about by the estrogen-induced proliferation and exfoliation of epithelial cells. In addition, this action may be supported by the higher sensitivity to estrogens (ER $\alpha$ content) found at $\mathrm{d} 0$.

Key words: estrus, sex steroid receptor, somatic cell count, dairy goat

\section{INTRODUCTION}

In the European Union, regulations specify the traits of hygiene and the bacteriological quality of goat milk. The law specifies the maximum allowable bacterial count in milk, but no threshold value is stipulated for SCC, in contrast to bovine milk. This is partially due to the wide variation found in this constituent in goat milk and the paucity of research. Somatic cell count is a widely implemented tool for indirect diagnosis of IMI in cows and it is used as a milk quality indicator. Intramammary infections caused by bacteria (Moroni et al., $2005 a, b)$ or by caprine arthritis-encephalitis virus (Sanchez et al., 2001) are well-known factors that cause a significant increase in SCC, but SCC in dairy goats is influenced by many other factors such as duration of lactation (Luengo et al., 2004), stage of lactation and parity (Wilson et al., 1995), and number of kids born (Luengo et al., 2004). Moreover, $75 \%$ of the variation in SCC in does free of IMI could not be explained (Wilson et al., 1995) and vast individual variation in daily SCC in mastitis-free goats was reported (Zeng et al., 1997).

The influence of estrus on SCC has been studied in dairy cows, but the results were contradictory. In dairy cows, it was demonstrated that injections of estrogens increase SCC independent of changes in milk yield (Haenlein and Krauss, 1974). Other studies in cows demonstrated no effect of estrous cycle stage on milk somatic cell concentration (Guidry et al., 1975; Anderson et al., 1983), or on milk yield and composition (fat, protein, total solids, and minerals; Cowan and Larson, 1979). Goats in southern Europe are seasonally polyestrous and breed efficiently when days are short (from 
August to February), so that estrous cycles occur with advanced stages of lactation. In anestrous dairy goats, McDougall and Voermans (2002) found that induced estrus (with an intravaginal progesterone-releasing device) increased SCC, but the physiological reasons for the increase in SCC were not examined. We have found no reports on the effect of spontaneous estrus on milk SCC in dairy goats.

The increase of SCC at estrus may be due to the effects of estrogens on the mammary gland. Estrogen action is mediated through interactions with its nuclear receptor (ER), which acts as a transcription factor and regulates gene expression (Clark et al., 1992). Two types of nuclear $\mathrm{ER}(\mathrm{ER} \alpha$ and $\mathrm{ER} \beta)$ have been described (Kuiper et al., 1997), but none has been described in the mammary gland of the goat. Cellular responsiveness to estrogens is dependent on ER expression; thus, mechanisms that modify receptor concentration may control the action of estrogens. In other ruminant tissues, ER $\alpha$ increases at estrus reinforcing estradiol action, which characterizes the follicular phase of the estrous cycle (Meikle et al., 2004). We hypothesize that the increase in SCC at estrus in the goat is not only associated with high circulating levels of estrogens, but also with a higher sensitivity of the mammary gland to estrogens (estrogen receptor contents).

The first experiment was conducted to assess the effect of the stage (proestrus and estrus, metestrus, and diestrus) of a spontaneous estrous cycle on SCC, milk yield, and milk composition (fat, protein, caseins, lactose, and urea) in dairy goats. The second was conducted under intensively controlled conditions, with the aim of understanding how circulating steroids affect daily SCC during a complete estrous cycle. Furthermore, sensitivity of the mammary gland to estrogens and progesterone was assessed by determination of $\mathrm{ER} \alpha$ and progesterone receptor (PR) by immunohistochemistry.

\section{MATERIALS AND METHODS}

\section{Study Farm}

Two experiments using Saanen goats were carried out during the breeding season (October to November 2004) on the same farm located in the north of Italy $\left(45^{\circ} \mathrm{N}, 10^{\circ} \mathrm{E}\right.$, altitude $\left.650 \mathrm{~m}\right)$. The farm was organically managed and the herd ( $\mathrm{n}=350$ lactating animals) was free of brucellosis, tuberculosis, and contagious agalactiae, and was seronegative to caprine arthritis-encephalitis virus. The farm practiced seasonal milking and the does kidded between February and March 2004. Experimental animals were housed in the same barn with free access to an open-air paddock. Each animal was identified by a microchip included in a ceramic bolus located in the reticulum. All of the animals received their diet according to lactation stage. Goats were offered a unified diet that consisted of a mixture of triticale silage, mixed grass hay and alfalfa hay, dried beet pulp, and a commercial concentrate $(1.59 \mathrm{Mcal}$ of $\mathrm{NE}_{\mathrm{L}} / \mathrm{kg}, 14.1 \% \mathrm{CP}$, as fed). Animals had free access to drinking water and commercial salt (Ovine Okin Salt; IZA srl. Evialis Group, Forli, Italy). After weaning, all goats were milked twice a day (with a rotating milking machine) without teat preparation. Neither teat dipping nor dry therapy was practiced.

The flock was enrolled in the recording scheme of Quality Milk Control, a project that focused on collection and analysis of data on milk yield and composition to provide management support to the farmer and to identify adequate management practices. Monthly testday records were conducted after weaning by technicians of the Provincial Breeding Association. Monthly samples of pooled milk were collected from every lactating goat during the entire lactation during the milking process and tested for SCC, fat, and protein concentrations. The daily milk yield was recorded at the same time. Bulk milk samples were collected for determination of bulk tank SCC, fat and protein concentration, and for microbiological analyses. No clinical signs of IMI were observed for any of the goats throughout the study, and hence, no mastitis therapy was administered.

\section{Animals}

Lactating goats $(\mathrm{n}=80)$ with 1 to 4 lactations and similar BCS ( $2.73 \pm 0.12$, mean \pm SEM; Santucci et al., 1991) were housed in external paddocks. Animals were classified by lactation number: $1(n=18), 2(n=28), 3$ $(n=17)$, and $>3$ lactations $(n=17)$. Animals were 7 to 9 mo in milk (266 $\pm 17 \mathrm{~d}$, mean \pm SD). Data regarding reproductive disease, mammary disease, or any other disease were recorded for each animal, and any animal showing signs of disease was excluded from the experiment. At the start of the breeding season, vasectomized males fitted with color markers were used to detect estrus. Vasectomized males were used to precisely confirm estrus, and not have the confounding effect of pregnancy on milk traits.

Experiment I. Estrus was recorded daily for $6 \mathrm{wk}$ in 80 lactating goats. Stages of the cycle were defined taking into consideration the day of detection of estrus (d 0) as follows: proestrus/estrus: $d-3$ to 0 ; metestrus: d 2 to 5; and diestrus: $d 7$ to 15 . Milk samples not included in these definitions were excluded for consideration from the analysis. Once weekly, during the morning milking, $100 \mathrm{~mL}$ of milk was sampled from all animals for determination of SCC, fat, protein, CN, lactose, 
and urea. Milk samples were preserved with sodium azide and kept refrigerated $\left(4^{\circ} \mathrm{C}\right)$ until analysis. Milk yield was recorded for all animals.

Experiment II. Goats ( $\mathrm{n}=14)$ in second lactation with similar BCS, and presenting estrus within $5 \mathrm{~d}$ were used. Milk samples $(20 \mathrm{~mL})$ were taken daily from d 0 until $4 \mathrm{~d}$ after the next estrus (about 25 samples per animal). Daily milk samples were collected from both half udders into 1 sterile vial: $10 \mathrm{~mL}$ was used for microbiological analysis, and the other $10 \mathrm{~mL}$ was preserved with sodium azide and kept refrigerated $\left(4^{\circ} \mathrm{C}\right)$ until SCC determination.

Blood samples $(10 \mathrm{~mL})$ were collected daily into heparinized tubes from the $\mathrm{d} 0$ until $4 \mathrm{~d}$ after the next estrus. Samples were centrifuged at $800 \times g$ for $10 \mathrm{~min}$ and plasma stored at $-20^{\circ} \mathrm{C}$ until progesterone (P4) and estradiol (E2) determinations.

Eight goats, selected at random, were slaughtered in accordance with the Council Directive 86/609/EE guidelines (EEC, 1986). The mammary glands were removed within 10 min of slaughter on predefined days of the estrous cycle: on the day of estrus $(\mathrm{d} 0, \mathrm{n}=4)$ and 10 $d$ after estrus ( $d 10, n=4)$. Samples of the mammary gland $(1 \times 1 \mathrm{~cm})$ were dissected and fixed with formalin and embedded in paraffin for immunohistochemistry. Blood samples for plasma P4 and E2 determination were collected from the 8 goats just before slaughter to confirm the stage of the estrous cycle.

\section{Microbiological Analysis}

Bacteriological culturing of daily milk samples from goats of experiment II was performed as previously described by Moroni et al. (2005a). Briefly, $10 \mu \mathrm{L}$ of each milk sample was spread on blood agar plates (supplemented with $5 \%$ of defibrinated sheep blood). The plates were incubated aerobically at $37^{\circ} \mathrm{C}$ and examined after $24 \mathrm{~h}$. The colonies were provisionally identified on the basis of Gram stain, morphology, and hemolysis patterns; the number of each colony type was recorded. The representative colonies were then subcultured on blood agar plates and incubated aerobically at $37^{\circ} \mathrm{C}$ for $24 \mathrm{~h}$ to obtain pure cultures. Catalase and coagulase production was tested for gram-positive cocci. Specific identifications of staphylococci and streptococci were made using commercial micromethods (API Staph and API 20 Strep; BioMérieux, Rome, Italy). Gram-negative isolates were identified by use of colony morphology, gram-staining characteristics, oxidase, and biochemical reactions on MacConkey's agar and API 20E (BioMérieux). The contagious pathogen Staphylococcus aureus was considered to cause IMI if at least 1 colony ( $>100 \mathrm{cfu} / \mathrm{mL}$ ) was isolated; for other microorganisms, IMI was defined by the isolation of $\geq 500 \mathrm{cfu} /$
$\mathrm{mL}$ and 1 to 3 colony types. Milk samples from which more than 3 colony types were isolated were regarded as contaminated; samples from which $<500 \mathrm{cfu} / \mathrm{mL}$ of any microorganism were isolated were regarded as uninfected. None of the 14 animals showed IMI, and no effect of the stage of the estrous cycle on the bacteriological status of the mammary glands was found. All mammary glands were considered healthy and any variation in SCC was not due to IMI.

\section{SCC Determination}

For each milk sample, the SCC was determined by an automated fluorescent microscopic somatic cell counter (Bentley Somacount 150, Bentley Instruments, Chaska, MN). Ethidium bromide dye was used for specific binding to the DNA in the cell nuclei.

\section{Milk Composition Determination}

Percentages of milk fat, protein and CN, lactose, and urea were determined on composite milk samples and assayed by an automated Fourier transform infrared absorption spectrophotometric analyzer (Milkoscan, Foss, Hillerød, Denmark).

\section{Hormone Determination}

Progesterone and E2 were determined daily from d 0 (estrus) to the next estrus. Progesterone was measured by a direct solid-phase RIA using commercial kits (Diagnostic Products Co., Los Angeles, CA) as previously described (Meikle et al., 1997). The analytical detection limit of the assay was $0.1 \mathrm{nmol} / \mathrm{L}$. The intraassay coefficient of variation was $8 \%$ at $1.5 \mathrm{nmol} / \mathrm{L}$, and $<6 \%$ at $6 \mathrm{nmol} / \mathrm{L}$. The interassay coefficients of variation were less than $11 \%$.

The estradiol 17- $\beta$ concentration was determined in all samples by a double-antibody RIA conducted using a kit (E2 double antibody, KE2D; Diagnostic Products Co.) as previously described (Meikle et al., 1997). The analytical detection limit of the assay was $2.6 \mathrm{pmol} / \mathrm{L}$. The intraassay coefficients of variation for low (14 pmol/ $\mathrm{L})$ and medium (45 pmol/L) controls were 23.6 and $6.2 \%$, respectively.

\section{Immunohistochemistry}

We used the avidin-biotin-peroxidase immunohistochemical technique to visualize $\mathrm{PR}$ and $\mathrm{ER} \alpha$ immunostaining in sections from the mammary glands (Meikle et al., 2000). Monoclonal mouse antibodies were used as primary antibodies: anti-PR (cat. no. 18-0172; Zymed, South San Francisco, CA) and anti-ER $\alpha$ (cat. no. sc- 
787; Santa Cruz Biotechnology, Santa Cruz, CA), diluted 1:100 and 1:25 in PBS, respectively. Negative controls for each receptor were obtained by replacing the primary antibody with nonimmune mouse IgG at equivalent concentration (cat. no. sc-2025; Santa Cruz Biotechnology). After primary antibody binding, the sections were incubated with a biotinylated horse antimouse IgG (Vectastain; Vector Laboratories, Burlingame, CA) diluted in normal horse serum. Thereafter, the tissue sections were incubated with a horseradish peroxidase-avidin-biotin complex (Vectastain Elite; Vector Laboratories). The location of the bound enzyme was visualized by $3,3^{\prime}$-diaminobenzidine in $\mathrm{H}_{2} \mathrm{O}_{2}$ (DAB kit; Vector Laboratories) and the sections were counterstained with hematoxylin and dehydrated before they were mounted. For each receptor, all samples were analyzed in the same immunohistochemical assay.

\section{Image Analysis}

After a general inspection of each slide, a subjective image analysis was performed to estimate the expression of PR and ER $\alpha$ in different cell types. The evaluation was performed by 2 independent observers who were unaware of the treatment group assignments. Only epithelial cells presented positive staining and 1,000 cells in each goat were evaluated for each receptor.

The staining of the nuclei was scored as negative $(-)$, faint $(+)$, moderate $(++)$, or intense $(+++)$ and the staining of each cell type was expressed in proportion on a scale of 0 to 10 . The average staining was calculated as $1 \times n_{1}+2 \times n_{2}+3 \times n_{3}$, where $n=$ number of cells per field exhibiting faint (1), moderate (2), and intense (3) staining (Boos et al., 1996).

\section{Statistical Analyses}

Milk yield, SCC, percentage of fat and protein, CN, lactose, and urea obtained in experiment I were analyzed by the MIXED procedure (Version 2000; SAS Institute Inc., Cary, NC). The statistical model included the effects of parity (1 to 4 lactations), stage of the cycle (proestrus/estrus, metestrus, diestrus), postpartum periods (234 to 259,260 to 284 , and 285 to $309 \mathrm{~d}$ postpartum), and their interactions. Goat within parity was set as a random effect. Tukey-Kramer tests were conducted to analyze differences between parities and stages. Data obtained from experiment II (E2 and P4 concentrations, SCC, and receptor content) were analyzed by a mixed procedure and the model included the effect of day of the cycle for steroid hormone concentrations and SCC or stage of the cycle (follicular vs. luteal phase) for receptor contents. Data are presented as least squares means \pm pooled standard error. Differences were considered significant if $P<0.05$.

\section{RESULTS}

\section{Experiment I}

Of the 80 goats, 74 exhibited cyclic activity as determined by visual observation of estrus during the $6 \mathrm{wk}$ of study. The mean length of the estrous cycle was 20.9 $\pm 0.24 \mathrm{~d}$ with a range from 19 to $22 \mathrm{~d}$. Data from the 6 goats that did not show estrus were excluded from the statistical analysis.

SCC. Parity $(P<0.01)$ and period of lactation $(P<$ 0.05) affected SCC. Third-lactation goats had higher SCC $\left(5,293 \pm 732 \times 10^{3}\right.$ cell $\mathrm{s} / \mathrm{mL}$, mean $\left.\pm \mathrm{SEM}\right)$ than first- and second-lactation goats $(3,066 \pm 649$ and 3,437 $\pm 563 \times 10^{3}$ cells $/ \mathrm{mL}$ ), which also had higher SCC than fourth-lactation goats $\left(1,864 \pm 666 \times 10^{3}\right.$ cells $\left./ \mathrm{mL}\right)$. A higher SCC was found in postpartum period 1 (234 to 259 DIM; 4,589 $\pm 577 \times 10^{3}$ cells $/ \mathrm{mL}$ ) compared with period 3 (285 to 309 DIM; $2,287 \pm 765 \times 10^{3}$ cells $/ \mathrm{mL}$ ).

Milk Yield and Composition. Only a significant effect of parity $(P<0.001)$ on milk yield was found; primiparous goats produced more milk $(838 \pm 53 \mathrm{~mL})$ than second- and fourth-lactation goats $(670 \pm 46$ and $692 \pm 55 \mathrm{~mL}$ ), which produced more than third-lactation goats $(513 \pm 60 \mathrm{~mL})$. Fat and lactose percentages were not affected by parity, stage of the estrous cycle, or postpartum period. Mean percentages of fat and lactose were $5.2 \pm 0.14 \%$ and $4.5 \pm 0.1 \%$, respectively. Protein and $\mathrm{CN}$ percentages were affected by the stage of the cycle $(P<0.01)$; a decrease in the percentage of both variables was observed during metestrus (Figure 1). The urea contents were affected by parity $(P<0.001)$ and postpartum period $(P<0.001)$; milk of third-lactation goats contained less urea $(34.6 \pm 0.9 \mathrm{mg} / 100 \mathrm{~mL})$ than that of first- $(38.9 \pm 0.8 \mathrm{mg} / 100 \mathrm{~mL})$, second- (37.3 $\pm 0.7 \mathrm{mg} / 100 \mathrm{~mL})$, and fourth- $(39.9 \pm 0.8 \mathrm{mg} / 100 \mathrm{~mL})$ lactation goats. The urea content increased as DIM increased: $35.2 \pm 0.7 \mathrm{mg} / 100 \mathrm{~mL}$ (postpartum period 1), to $37.5 \pm 0.5 \mathrm{mg} / 100 \mathrm{~mL}$ (postpartum period 2), and $40.2 \mathrm{mg} / 100 \mathrm{~mL}$ (postpartum period 3).

\section{Experiment II}

Estrous Cycle. Of the 14 dairy goats that exhibited cyclic activity, as determined by the detection of estrus and by $\mathrm{P} 4$ and $\mathrm{E} 2$ concentrations in the plasma, 1 animal had luteal P4 until d 32 after estrus and was excluded from the analysis. Figure 2 displays the mean P4 and E2 levels of the 13 goats. There was an effect of the day of the cycle on P4 and E2 levels $(P<0.0001)$ and both endocrine profiles were as expected: high E2 concentrations around estrus and high P4 concentra- 


\section{$\square$ Proestrus/Estrus $\square$ Metestrus $\square$ Diestrus}

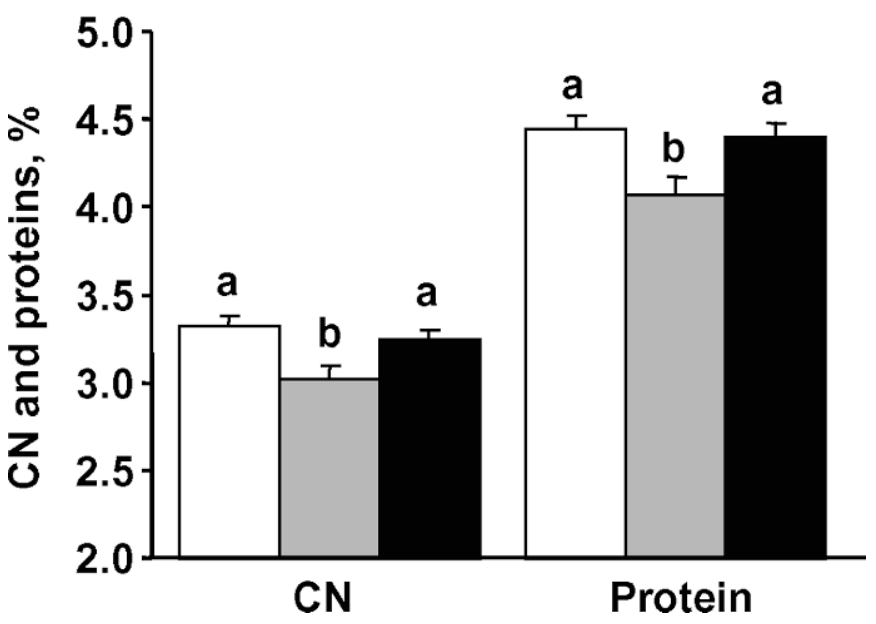

Figure 1. Percentage of $\mathrm{CN}$ and proteins in goat milk in different stages of the estrous cycle (proestrus/estrus, metestrus, and diestrus). ${ }^{\mathrm{a}, \mathrm{b}}$ Bars with different letters differ at $P<0.05$.

tions during the luteal phase $(P<0.01)$. The mean $\mathrm{P} 4$ concentrations around $\mathrm{d} 20$ in Figure 2 did not reach basal levels (e.g., $<1 \mathrm{nmol} / \mathrm{L}$ ) because the length of the estrous cycle differed among goats (range of the length of the cycle: 19 to $21 \mathrm{~d}$ ). For the same reason, mean E2 concentrations in Figure 2 around d 20 were lower than at $\mathrm{d} 0$.

SCC. There was an effect of day of the cycle on SCC $(P<0.0001)$. Maximum levels of SCC were observed at the day of estrus, decreased immediately thereafter, and reached the lowest levels during the luteal phase. Somatic cell count began to increase again at d 19 after estrus and was associated with luteal regression (e.g., decreasing $\mathrm{P} 4$ levels) and increasing plasma concentrations of E2 (Figure 2). Thus, there was a negative correlation between SCC and P4 ( $\mathrm{r}=-0.43, P<0.0001, \mathrm{n}=$ 253) and a positive correlation between SCC and E2 $(\mathrm{r}=0.38, P<0.0001, \mathrm{n}=163)$.

Mammary Gland Immunohistochemistry. The stage of the estrous cycle of the 8 lactating goats sampled for mammary tissue was confirmed by P4 and E2 plasma concentrations (data not shown). Progesterone receptor and $\mathrm{ER} \alpha$ immunoreactivity was seen exclusively in the nuclei (not cytoplasm) of alveolar-epithelial cells. Adipocytes and cells of the vascular system (endothelial cells and smooth muscle cells) were devoid of specific staining (data not shown). When monoclonal specific antibodies were substituted by a nonimmune mouse IgG, the absence of staining demonstrated the specificity of the immunostaining of both receptors. The percentages of $\mathrm{ER} \alpha$-positive nuclei at $\mathrm{d} 0$ and 10 are shown in Figure 2. Although most alveolar-epithelial cells were positive for $\mathrm{ER} \alpha$ at both $\mathrm{d} 0$ and 10, more positive nuclei were found on $d 0$. In contrast, only about $5 \%$ of alveolar-epithelial cells were positive for PR and no differences were found in the percentage of positive nuclei on $\mathrm{d} 0$ and 10 (data not shown). The average staining proportion was higher at $\mathrm{d} 0$ than at d 10 for $\operatorname{ER} \alpha(1.44 \pm 0.02$ vs. $1.35 \pm 0.02 ; P<0.01)$ and

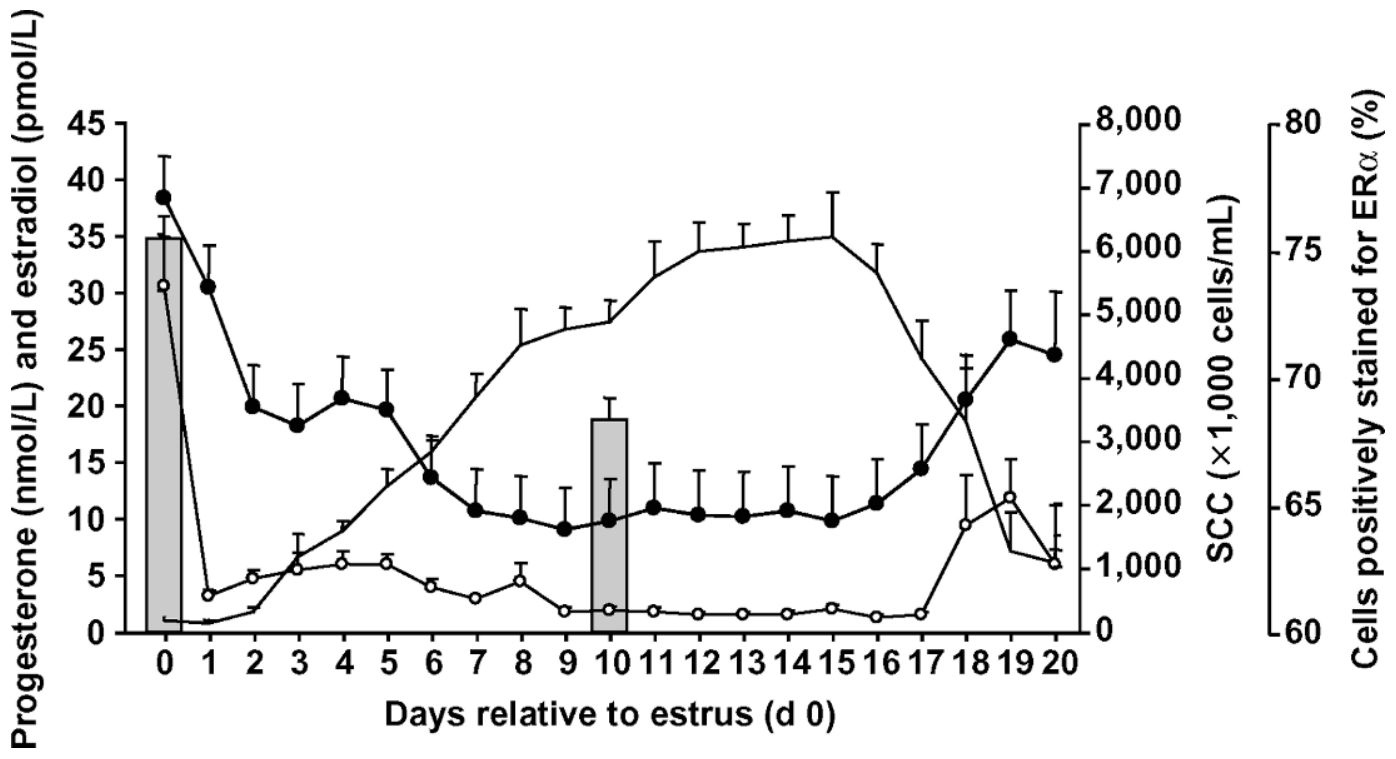

Figure 2. Mean ( \pm SEM) daily levels of progesterone (nmol/L, solid line), estradiol (pmol/L, open circles), SCC $(\times 1,000$ cell $/ \mathrm{mL}$, solid dots) and percentage $(\%$, bars) of mammary gland cells positively staining for estrogen receptor (ER $\alpha)$ on d 0 and 10 during the estrous cycle of the doe in experiment II. 

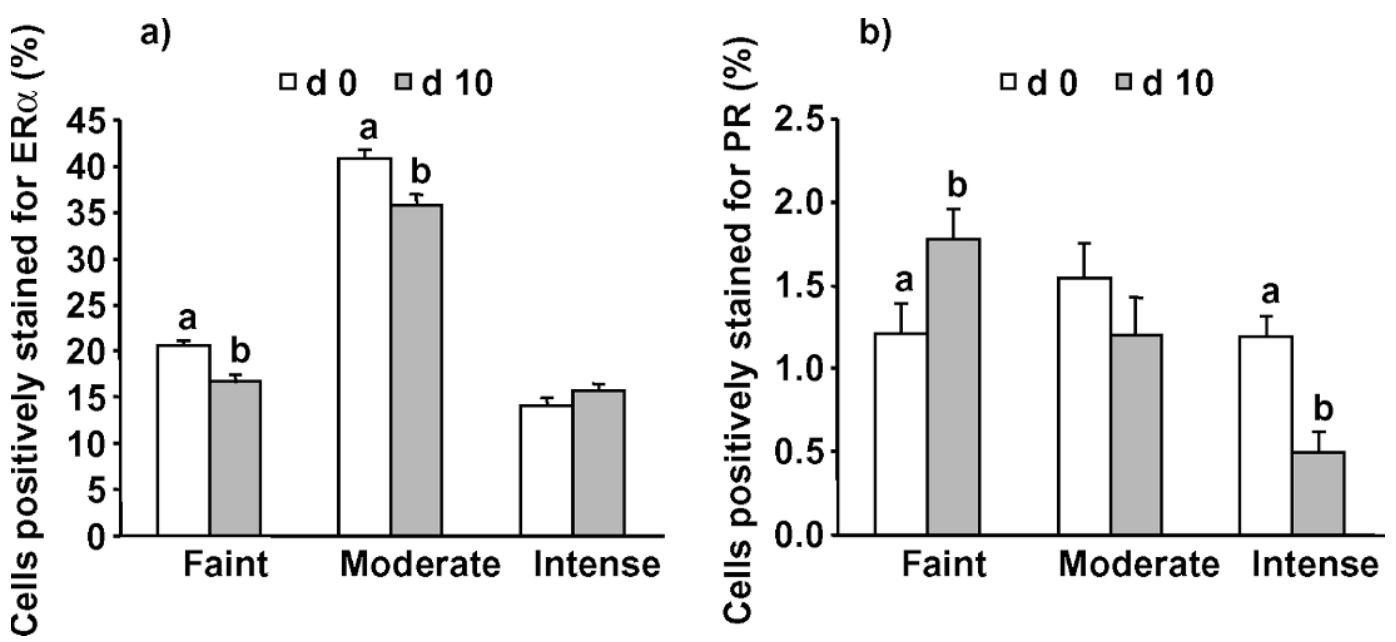

Figure 3. Faint, moderate, and intense staining of cells of the mammary gland cells positively staining for a) estrogen (ER $\alpha$ ) and b) progesterone receptors (PR) on d 0 and 10 of the estrous cycle of does in experiment II. ${ }^{\mathrm{a}, \mathrm{b}}$ Bars with different letters differ at $P<0.05$.

PR $(0.079 \pm 0.007$ vs. $0.057 \pm 0.007 ; P<0.05)$. The percentages of low, moderate, and intense staining of nuclei for ER $\alpha$ and PR are shown in Figure 3. On d 0, more faintly and moderately stained cells for $\mathrm{ER} \alpha$ were found than on $d$ 10. More intensely stained, but fewer faintly stained, cells were found for PR on d 0 than on d 10.

\section{DISCUSSION}

In this study we have shown that SCC in goats is affected by the day of the estrous cycle presenting maximum levels at estrus. The SCC profile is associated with the endocrine environment; for example, higher SCC levels were accompanied by high E2 and basal P4 concentrations. To our knowledge, this is the first report on $\mathrm{ER} \alpha$ and PR immunolocalization in the mammary gland of the goat, and the $\mathrm{ER} \alpha$ expression is regulated in a cyclic manner as occurs in other tissues.

Somatic cell count is used as an index of milk quality for cow, sheep, and goat milk. Milk SCC for uninfected goats is higher than SCC for uninfected cows (cows: 40 to $80 \times 10^{3} / \mathrm{mL}$; goats: 50 to $400 \times 10^{3} / \mathrm{mL}$; Dulin et al., 1983). The relationship between SCC and the microbiological quality of milk of small ruminants remains controversial (Park and Humphrey, 1986). The SCC seems to be influenced by various factors such as stage of lactation, parity, time of sampling (before, during, or after milking), stress, and kidding season in dairy goats (Haenlein, 2002) and lambing in sheep (Sevi et al., 2004). Moreover, Wilson et al. (1995) reported that more than $90 \%$ of the variation in milk SCC in goats was not due to IMI; increasing DIM and month of the year were among the most important factors contributing to in- creased cell count in the absence of IMI, which our results support.

In experiment II we found an effect of the stage of the estrous cycle on SCC that could explain part of the reported SCC variation in goats; SCC increased during proestrus and estrus. The almost 4 -fold increase in SCC found on the day of estrus suggests that this is due to the estrogenic action that characterizes this period. Differences were found in SCC among experiments. Diestrus SCC values were similar to this stage in experiment I, but were basal in experiment II. There is no obvious explanation for this finding, except that experiment II was a controlled design in which the stage of the cycle was confirmed by daily hormone concentrations and milk was sampled daily, whereas stages in experiment I were defined only according to the day of estrus and milk was sampled weekly, leading to lower precision in the milk sampling. Thus, a once-a-month testing schedule in individual animals is inappropriate if SCC is to be used as an indicator of IMI or milk quality.

In experiment I we observed a significant effect of postpartum period on SCC with a decreasing trend from mo 8 to 10 of lactation. Zeng et al. (1997) observed this variation, as they demonstrated that dairy goats in late lactation had daily SCC that fluctuated markedly. Other than postpartum period, parity affected SCC significantly, which supports other studies in which SCC increased from first to greater parities (Wilson et al., 1995). Fourth-parity goats had significantly lower SCC values than other parities; this may be explained by the progressive culling of older animals with problems of high SCC during the previous lactation. 
Milk composition is important to the goat cheese manufacturer, because any factor that influences milk composition (especially protein and $\mathrm{CN}$ content) also influences cheese properties, quality, yield, and economic returns (Storry et al., 1983). In experiment I, higher levels of protein and CN were found at proestrus/ estrus, suggesting a positive effect of E2. Casein percentage was affected by parity; first-lactation goats had greater $\mathrm{CN}$ content than goats with greater parities, which is in agreement with the findings of Hayes et al. (1984) in dairy cows.

Milk yield was significantly affected by parity. Over the 6 -wk period, higher milk yield was recorded for first-lactation goats than for second- to fourth-lactation goats. These data do not reflect total milk yield during the entire lactation by parity. Moreover, in an analysis of the data obtained from the milk quality controls of the herd, we observed a significant increase in total milk yield from first- to fourth-lactation goats (data not shown). One possible explanation for the effect of parity on milk yield is that first-parity goats may be characterized by a greater duration of lactation and daily milk yield in late lactation (234 to 309 d postpartum) compared with higher parity goats. Gipson and Grossman (1989) found a negative relationship between shape of the lactation curve and parity because the time of peak yield generally was later in lactation for first-parity does than for more advanced parity does with consequent longer duration of the second phase of lactation.

Milk urea can be used to monitor nutritional imbalances in dietary protein, but requires the identification of nonnutritional factors (e.g., effect of estrus) that may influence it. We hypothesized a possible effect of stress associated with estrus on feeding and metabolism, but no significant effect of the cycle stage was observed. On the other hand, milk urea was affected by parity and postpartum period, supporting previous results in dairy cows (Hojman et al., 2004).

The genomic action of E2 is mediated via its respective receptors (ER). We have shown that the epithelial cells of the goat mammary gland contain ER $\alpha$. Strong positive staining in most epithelial cells was reported in the bovine mammary gland, and, as in this study, endothelial cells and smooth muscle cells were consistently negative (Schams et al., 2003). In contrast, the latter study reported no immunoreactions of $\mathrm{ER} \alpha$ in the mammary gland during late galactopoiesis, whereas we found that more than $60 \%$ of the epithelial cells were $\mathrm{ER} \alpha$ positive. There is no obvious explanation for this discrepancy other than the species difference. Moreover, we found that very few cells were positive for PR, which is consistent with previous studies that reported that lactation decreases PR in the mammary gland
(Varas and Jahn, 2005) and that PR is undetectable during lactation (Wiehle and Wittliff, 1983).

The high SCC at estrus in experiment II might have been due to epithelial proliferation and exfoliation induced by E2 and could be supported by increased sensitivity of the mammary gland to estrogens; that is, the $\mathrm{ER} \alpha$ increase found at estrus. Finally, during the luteal phase, $\mathrm{P} 4$ antagonizes estrogen action because it inhibits ER $\alpha$ expression as shown in other tissues (Clark et al., 1992) and this is consistent with a simultaneous decrease in SCC. Thus, on d 10, the lower SCC levels can be explained by lower sensitivity of the mammary gland to E2, which could be due to $\mathrm{P} 4$ dominance, low E2 levels, or both.

\section{CONCLUSIONS}

Somatic cell count, CN, and protein percentage in goat milk were affected by stage of the estrous cycle. The increase of SCC at estrus was associated with elevated plasma estradiol, suggesting that it could be the result of an estrogen-induced exfoliation of epithelial cells; this, in turn, could be supported by the higher sensitivity of the mammary gland to E2 (ER $\alpha$ content) found at this stage.

\section{ACKNOWLEDGMENTS}

The authors express their gratitude to the supervisor of the dairy goat farm and to Isabel Sartore for technical assistance.

\section{REFERENCES}

Anderson, K. L., A. R. Smith, S. L. Spahr, B. K. Gustafsson, E. Hixon, P. G. Weston, E. H. Jaster, R. D. Shanks, and L. Whitmore. 1983. Influence of the estrus cycle on selected biochemical and cytologic characteristics of milk of cows with subclinical mastitis. Am. J. Vet. Res. 44:677-680.

Boos, A., W. Meyer, R. Schwarz, and E. Grunert. 1996. Immunohistochemical assessment of estrogen receptor and progesterone receptor distribution in biopsy samples of the bovine endometrium collected throughout the oestrous cycle. Anim. Reprod. Sci. 44:11-21.

Clark, J. H., W. T. Schrader, and B. W. O'Malley. 1992. Mechanisms of steroid hormones action. Pages 35-90 in Textbook of Endocrinology. J. D. Wilson and D. W. Foster, ed. W. B. Saunders, Philadelphia, PA.

Cowan, C. M., and L. L. Larson. 1979. Relationship of the estrous cycle to milk composition. J. Dairy Sci. 62:546-550.

Dulin, A. M., M. J. Paape, W. D. Schultze, and B. T. Weinland. 1983. Effect of parity, stage of lactation, and intramammary infection on concentration of somatic cells and cytoplasmic particles in goat milk. J. Dairy Sci. 66:2426-2433.

EEC (European Economic Community). 1986. Council Directive 86/ 609/EEC: On the approximation of laws, regulations, and administrative provisions of the Member States regarding the protection of animals used for experimental and other scientific purposes. Off. J. L 358:1-28.

Gipson, T. A., and M. Grossman. 1989. Diphasic analysis of lactation curves in dairy goats. J. Dairy Sci. 72:1035-1044. 
Guidry, A. J., M. J. Paape, and R. E. Pearson. 1975. Effects of estrus and exogenous estrogen on circulating neutrophils and milk somatic cell count concentration, neutrophil phagocytosis, and occurrence of clinical mastitis in cows. Am. J. Vet. Res. 36:15551560 .

Haenlein, G. F. W. 2002. Relationship of somatic cell counts in goat milk to mastitis and productivity. Small Rumin. Res. 45:163-178.

Haenlein, G. F. W., and W. C. Krauss. 1974. Effects of single injections of diethylstilbestrol on milk composition and counts of leucocytes in milk of Holstein-Friesian cattle. Z. Tierphysiol. Tierernahr. Futtermittelkd. 34:50-60.

Hayes, J. F., K. F. Ng-Kwai-Hang, and J. E. Moxley. 1984. Heritability of milk casein and genetic and phenotypic correlations with production traits. J. Dairy Sci. 67:841-846.

Hojman, D., O. Kroll, G. Adin, M. Gips, B. Hanochi, and E. Ezra. 2004. Relationships between milk urea and production, nutrition, and fertility traits in Israeli dairy herds. J. Dairy Sci. 87:10011011.

Kuiper, G. G. J. M., B. Carlsson, K. Grandien, E. Enmark, J. Häggblad, S. Nilsson, and J. A. Gustafsson. 1997. Comparison of the ligand binding specificity and transcript tissue distribution of estrogen receptors $\alpha$ and $\beta$. Endocrinology 138:863-870.

Luengo, C., A. Sanchez, J. C. Corrales, C. Fernandez, and A. Contreras. 2004. Influence of intramammary infection and non-infection factors on somatic cell counts in dairy goats. J. Dairy Res. 71:169-174.

McDougall, S., and M. Voermans. 2002. Influence of estrus on somatic cell count in dairy goats. J. Dairy Sci. 85:378-383.

Meikle, A., M. Forsberg, L. Shalin, B. Masironi, C. Tasende, M. Rodríguez-Piñón, and E. G. Garóófalo. 2000. A biphasic action of estradiol on estrogen and progesterone receptor expression in the lamb uterus. Reprod. Nutr. Dev. 40:283-293.

Meikle, A., C. Tasende, M. Rodriguez, and E. G. Garofalo. 1997. Effects of estradiol and progesterone on the reproductive tract and on uterine sex steroid receptors in female lambs. Theriogenology 48:1105-1113.

Meikle, A., C. Tasende, C. Sosa, and E. G. Garófalo. 2004. The role of sex steroid receptors in sheep female reproductive physiology. Reprod. Fertil. Dev. 16:1-10.

Moroni, P., G. Pisoni, G. Ruffo, and P. J. Boettcher. 2005a. Risk factors for intramammary infections and relationship with somatic cell counts in Italian dairy goats. Prev. Vet. Med. 69:163-173.
Moroni, P., G. Pisoni, G. Ruffo, I. Cortinovis, and G. Casazza. 2005b. Study of intramammary infections in dairy goats from mountainous regions in Italy. N.Z. Vet. J. 53:375-376.

Park, Y. W., and R. D. Humphrey. 1986. Bacterial cell counts in goat milk and their correlations with somatic cell counts, percent fat, and protein. J. Dairy Sci. 69:32-37.

Sanchez, A., A. Contreras, J. C. Corrales, and J. C. Marco. 2001. Relationships between infection with caprine arthritis encephalitis virus, intramammary bacterial infection and somatic cell counts in dairy goats. Vet. Rec. 148:711-714.

Santucci, P. M., A. Branca, M. Napoleone, R. Boche, F. Poisot, G. Aumont, and G. Alexandre. 1991. Body condition score of goats in extensive condition. Pages 240-255 in Goat Nutrition. Vol. 46. Pudoc Publ., Wageningen, the Netherlands.

Schams, D., S. Kohlenberg, W. Amselgruber, B. Berisha, M. W. Pfaffl, and F. Sinowatz. 2003. Expression and localisation of oestrogen and progesterone receptors in the bovine mammary gland during development, function and involution. J. Endocrinol. 177:305317.

Sevi, A., M. Albenzio, R. Marino, A. Santillo, and A. Muscio. 2004. Effects of lambing season and stage of lactation on ewe milk quality. Small Rumin. Res. 51:251-259.

Storry, J. E., A. S. Grandison, D. Millard, A. J. Owen, and G. D. Ford. 1983. Chemical composition and coagulating properties of renneted milk from different breeds and species of ruminants. J. Dairy Res. 50:215-229.

Varas, S. M., and G. A. Jahn. 2005. The expression of estrogen, prolactin, and progesterone receptors in mammary gland and liver of female rats during pregnancy and early postpartum: regulation by thyroid hormones. Endocr. Res. 31:357-370.

Wiehle, R. D., and J. L. Wittliff. 1983. Alterations in sex-steroid hormone receptors during mammary gland differentiation in the rat. Comp. Biochem. Physiol. B 76:409-417.

Wilson, D. J., K. Stewart, and P. M. Sears. 1995. Effects of stage of lactation, production, parity and season on somatic cell counts in infected and uninfected dairy goats. Small Rumin. Res. 16:165-169.

Zeng, S. S., E. N. Escobar, and T. Popham. 1997. Daily variations in somatic cell count, composition, and production of Alpine goat milk. Small Rumin. Res. 26:253-260. 